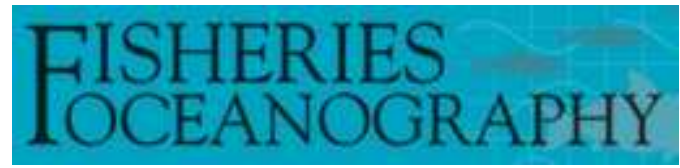

\title{
Environmental control of North East Atlantic mackerel (Scomber scombrus) recruitment in the Southern Bay of Biscay: Study case of the failure of year $\mathbf{2 0 0 0}$
}

\begin{tabular}{|c|c|}
\hline Journal: & Fisheries Oceanography \\
\hline Manuscript ID: & Draft \\
\hline Manuscript Type: & Original Article \\
\hline \multicolumn{2}{|l|}{$\begin{array}{r}\text { Date Submitted by the } \\
\text { Author: }\end{array}$} \\
\hline Complete List of Authors: & $\begin{array}{l}\text { Villamor, Begoña; Instituto Español de Oceanografía, Centro } \\
\text { Oceanográfico de Santander } \\
\text { Gonzalez-Pola, Cesar; Instituto Español de Oceanografía, Centro } \\
\text { Oceanográfico de Gijon } \\
\text { Lavin, Alicia; Instituto Español de Oceangrafía, Centro } \\
\text { Oceanografico de Santander } \\
\text { Valdes, Luis; Intergovernmental Oceanographic Commission of } \\
\text { UNESCO } \\
\text { Lago de Lanzós, Ana; Instituto Español de Oceanografía } \\
\text { Franco, Concha; Instituto Español de Oceanografía } \\
\text { Cabanas, Jose Manuel; Instituto Español de Oceanografía, Centro } \\
\text { Oceanografico de Vigo } \\
\text { Bernal, Miguel; Instituto Español de Oceanografia, Centro } \\
\text { Oceanografico de Cadiz } \\
\text { Hernandez, Carmen; Instituto Español de Oceanografía, Centro } \\
\text { Oceanografico de Santander } \\
\text { Iglesias, Magdalena; Instituto Español de Oceanografía, Centro } \\
\text { Oceanografico de Baleares } \\
\text { Carrera, Pablo; Museo do Mar de Galicia } \\
\text { Porteiro, Carmela; Instituto Español de Oceanografía, Centro } \\
\text { Oceanografico de Vigo }\end{array}$ \\
\hline Keywords: & $\begin{array}{l}\text { Bay of Biscay }<\text { region, mackerel }<\text { fish }<\text { taxon, advection }< \\
\text { oceanography, turbulence }<\text { oceanography, wind }<\text { oceanography, } \\
\text { larva }<\text { biology, juvenile }<\text { biology, growth }<\text { biology, birth }< \\
\text { biological dynamics, recruitment }<\text { biological dynamics, survival }< \\
\text { biological dynamics }\end{array}$ \\
\hline
\end{tabular}

\section{(5) ScholarONE"




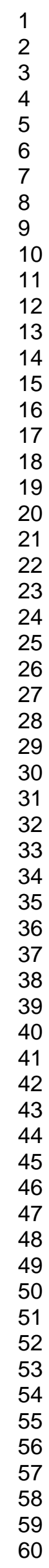 \\ Page 1 of 55}

1

2

4

5

7

8

10

11

12

15

16

17

19

20

22

23

25

26

28

30

31

33

34

36

37

38

39

40

41

42

44

45

46

47

48

49

50

52

53

54

56

57

58

60

Fisheries Oce

1

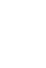

.

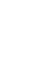

.




\title{
Environmental control of North East Atlantic mackerel (Scomber
} scombrus) recruitment in the Southern Bay of Biscay: Study case of the failure of year 2000.

\author{
B. VILLAMOR ${ }^{1, *}$, C. GONZALEZ-POLA ${ }^{2}$, A. LAVÍN ${ }^{1}$, L. VALDÉS ${ }^{3}$, A. LAGO
} DE LANZÓS ${ }^{4}$, C. FRANCO $^{4}$, J.M. CABANAS ${ }^{5}$, M. BERNAL ${ }^{6}$, C. HERNANDEZ ${ }^{1}$, M. IGLESIAS ${ }^{7}$, P. CARRERA ${ }^{8}$, AND C. PORTEIRO ${ }^{5}$

${ }^{1}$ Instituto Español de Oceanografía (IEO), Centro Oceanográfico (C.O.) de Santander, Promontorio de San Martín s/n , 39080 Santander, Spain

${ }^{2}$ IEO-C.O. de Gijón, c/ Príncipe de Asturias 70 Bis, 33212 Gijón (Asturias), Spain

${ }^{3}$ Intergovernmental Oceanographic Commission of UNESCO, 1 rue Miollis, 75732 Paris, Cedex 15 France.

${ }^{4}$ IEO-Madrid, Avda. de Brasil 31, 28020 Madrid, Spain.

${ }^{5}$ IEO-C.O. de Vigo, Cabo Estay Canido s/n, 36200 Vigo, Spain.

${ }^{6}$ IEO-C.O. de Cádiz, Puerto Pesquero, Muelle de Levante s/n, 11006 Cadiz, Spain.

${ }^{7}$ IEO-C.O de Baleares, Muelle de Poniente s/n, 07015 Palma de Mallorca, Spain

${ }^{8}$ Museo do Mar de Galicia. Avda Atlántida s/n Vigo, Spain

*Correspondence. E-mail: begona.villamor@st.ieo.es

Running title: Mackerel recruitment and environmental conditions 


\begin{abstract}
The effect of early-spring strong meteorological perturbations in the success of mackerel (Scomber scombrus) recruitment in the N/NW Iberian area (South of the Bay of Biscay) is explored for the period 1999-2008. The work is motivated by the case of the most pronounced recruitment failure on record in year 2000, when two consecutive multidisciplinary surveys focused on the study of mackerel early life stages survival took place. Year 2000 cruises showed an intriguing picture where larvae found during the second survey were younger than larvae captured during the first one. The later birthdate analysis from otoliths of mackerel juveniles caught between July and October 2000 showed the non-existence of survivors from the early spring spawns, indicating a massive loss of early spawning effort, and the abundance of one-year-old mackerel estimated from 2001 acoustic survey was the lowest observed from the 1999 to 2008 yearly series. The causes of this low or null survival from the early spawns in 2000 could be found in the particular meteorological and oceanographic conditions present that spring. Two stormy events in April after a relatively calm March hit the area, the fist one from the north caused strong local wind at the southern Biscay but weak oceanographic response, while the second event from the southwest was mainly felt west of Galicia but caused a notable enhancement of shelf currents and a shift of the hydrographical structure along the shelf. The detailed analysis of early-spring strong wind pulses within the historical recruitment record suggest that either strong local turbulence generated by high wind speed, as well as advection of larvae caused by enhancement of shelf currents, may induce poor recruitments. In the case of the extreme failure of year 2000 both mechanisms were present.
\end{abstract}

Key words: Scomber scombrus, mackerel, recruitment, larval distribution, birthdate distribution, environmental conditions 


\section{INTRODUCTION}

This work presents a multidisciplinary approach to analyse mackerel (Scomber scombrus Linnaeus, 1758) population dynamics in the north-northwest of the Iberian peninsula area. Yearly acoustic surveys, oceanographic-biological cruises including ichthyoplankton sampling, juvenile otoliths analysis as well as large-scale and local wind forcing analyses contributes to explore the possible causes behind success or failure in mackerel recruitment.

Determining the factors that affect the recruitment process of fish populations is central to understanding fish population dynamics and predicting responses to exploitation. Extensive research field and reviews have been conducted in order to improve the knowledge on the relationships among spawning stock biomass, environmental conditions and the subsequent offspring. (Hjort, 1914; Paulik, G.J. 1973; Myers, 2001; Koster et al., 2003). From these studies it was stated that the strength of the recruitment of many species is largely determined during their first life stages. Therefore, much effort has been put to explain recruitment variation through models determining the egg or larval mortality on account several factors such as density dependent relationships between spawning stock and recruitment (Ricker, 1954; Beverton and Holt, 1957), predation on eggs and larvae (Bailey and Houde, 1989), relationships between larval survival and the temporal or spatial availability of suitable preys and/or oceanographic conditions (Hjort, 1926; Marr 1956; May 1974; Cushing R., 1981; Cushing D.H., 1990; Lasker, 1981; Parrish et al., 1981; Iles and Sinclair, 1982). However, the complex set of interactions existing in any ocean ecosystem among its different compartments make it difficult to establish simple relationships that prove to be robust year after year. Recent approaches to the problem seek for the construction of very complex models of the ecosystem as a whole, including larvae growing and mortality (Bartsch and Coombs, 2001; Gallego et al., 2007; Miller, 2007). The search of 
environmental limiting factors to the recruitment through quantile regression models instead of trying to track linear relationships for both success and failure against the same environmental factor have recently yielded interesting results (Planque and Buffaz, 2008).

On commercial fish stocks widely distributed, interannual variation in recruitment leads to international coordination in research fields in order to get a better understanding of the stock dynamics and to improve the management of the fisheries on account such variability. Northeast Atlantic mackerel (NEAM) is widely distributed throughout European coasts and the migratory routes the species follows in this area are well known (Uriarte et al., 2001). Since 1995, ICES (1996) has considered NEAM to be a single stock, assuming the existence of three spawning components (ICES, 2000) located at western European waters (ICES areas VI, VII and VIIIabde), southern European waters (VIIIc and IXa) and in the North Sea and Skagerrak (IIIa and IV) (Fig. 1).

Main spawning area for the southern component occurs in the Cantabrian Sea (Division VIIIc), from February to June, peaking in April (Solá et al., 1990). Eggs are widely distributed over the continental shelf and offshore (Lago de Lanzós et al., 1993) whilst recruitment mainly occurs in Sub-Division IXa North, during the second part of the year at length ranging from 15 to $20 \mathrm{~cm}$ (Villamor et. al, 1997; Villamor, 2007).

Both fishery data and surveys are routinely conducted in order to assess this stock. While international triannual eggs surveys (ICES, 2005) and international projects such as SEFOS or SEAMAR (SEFOS, 1997; SEAMAR, 2002) had improved the knowledge on early life stages, specially egg distribution, and oceanographic conditions, the use of new acoustic multi-frequency devices and post-processing acoustic analysis allowed non swimbladder fish species such as mackerel be assessed by means of acoustic methods (PELASSES, 2002; ICES, 2002a). Since 1998 the 
coordinated acoustic surveys on pelagic fish species present in the Spanish and French waters, which are routinely carried out in spring (ICES, 1998 and 2008a), are conducted on board R. V. Thalassa, using multi-frequency. Methods and scope of these multidisciplinary surveys are described in PELASSES (2002) and Iglesias et al. (2005). From the results of these surveys, a recruitment index for mackerel has been derived.

The index of mackerel recruitment is calculated for the period 1999-2008 as the proportion of one-year-old mackerel abundance respect to the total mackerel abundance estimated each year according to the interpretation of the annual growth and elaboration of age length key of mackerel (Villamor et al., 2004a). The Index time series is shown in Figure 2. As expected, the time series shows a great variability with 2001 year giving the lowest contribution of the age group 1 (only $1.5 \%$ to the total abundance estimated for this particular year), while 2003 age 1 contributed up to $80 \%$ of the total abundance. Analytical assessment agrees with this perception, being 2000 year class one of lowest year class estimates and 2002 year class the highest in the large time series (from 1972) of the whole stock. (ICES, 2008b)

As stated previously, large recruitment variability is expected due to several natural factors related with the environmental conditions during the critical period of larval development and therefore the variability of mackerel recruitment could be driven by the variability in the oceanographic conditions. At spawning period and larvae development of mackerel, oceanographic conditions are mainly characterised by relative calm periods breaking by short storms periods. (Torres et al., 2003) and consequently meso-scale dynamics are important in the system as suggested in Borja et al., (2002), but the precise relationship or mechanism of interaction with the larvae remains a matter of concern. On account the results of two consecutive multidisciplinary cruises carried in spring 2000 on the frame of the SEAMAR Project (SEAMAR, 2002), the relationships between this weak recruitment and the environmental conditions were 
studied. Also, we explore the long-term mackerel recruitment series in relation to the strong wind-events. 


\section{MATERIAL AND METHODS}

Two consecutive multidisciplinary surveys, including ichthyoplankton and hydrographic sampling, were carried out covering the main mackerel spawning grounds (off the north and northwest coasts of the Iberian Peninsula). The surveys were conducted on board the R.V. Cornide de Saavedra (SEAMAR 0400 -hereinafter SM04from March $28^{\text {th }}$ to April $15^{\text {th }}$ and SEAMAR 0500 -hereinafter SM05- from April $25^{\text {th }}$ to May $15^{\text {th }}$ ) covering the same survey grid (Fig. 3). The cruises consisted on two different legs. The first leg covered the whole expected spawning area with a large grid of $0.250^{\circ} \times 0.500^{\circ}$, sampled westward from Vigo to Santander, aiming at to characterise the main hydrological features of the surveyed area. The second leg was focussed on mesoscale features with a sampling grid of $0.125^{\circ} \times 0.250^{\circ}$, one located in the inner Bay of Biscay (Biscay area) and the other off the west Cantabrian coast (Ortegal area), covered eastward.

Vertical profiles of temperature, salinity, in situ fluorescence and photosynthetically-active irradiance (PAR) were measured with a CTD Seabird SBE-25 at a series of stations arranged in sections perpendicular to the coast up to $600 \mathrm{dbar}$ (approximately 600 meters) in most of the deeper stations in order to get a proper reference level for geostrophic velocity field computation.

Plankton sampling was carried out at each station with oblique Bongo-50 net tows with $250 \mu \mathrm{m}$ mesh to a depth of $200 \mathrm{~m}$, or $5 \mathrm{~m}$ above the bottom at shallower stations. General Oceanics flowmeters were used to estimate the distance covered by the net. The filtered volume in each haul was calculated assuming $100 \%$ filtration efficiency. After washing the nets, mackerel larvae were sorted from one of the Bongo nets for growth and mortality studies. The rest of the sample was fixed in $4 \%$ fresh water formaldehyde solution neutralized with borax for later study in the laboratory. The plankton from the other net was fixed in formaldehyde for biomass studies after the 
extraction of eggs and larvae taken for studies of egg mortality and larval condition, and for daily growth studies. For biomass studies each sample was fractionated by successive filters to obtain the fractions $200-500,500-1000 \mu \mathrm{m}, 1-2,2-5$ and $>5 \mathrm{~mm}$. These sub-samples were dried at $60{ }^{\circ} \mathrm{C}$ for calculation of the dry weight biomass. To obtain the post-larvae, tows were made with a neuston MIK (Method of Isaac Kidd) and RMT (rectangular mid-trawl) nets, with $1 \mathrm{~mm}$ mesh size. Specimens were measured [standard length $\left(\mathrm{L}_{\mathrm{S}}\right)$ ] to the nearest $0.1 \mathrm{~mm}$ to provide information on the sizefrequency distribution and daily growth studies. Each measured larvae was preserved individually in test tubes with $80 \%$ tris buffered alcohol solution $(\mathrm{pH} 8.5)$. Unmeasured mackerel larvae were similarly preserved in alcohol for later otolith extraction. In order to obtain a conversion factor from fresh to fixed alcohol, a larvae sample covering the whole length range with at least five individuals was measured on board. A total of 1126 (446 in April and 680 in May) mackerel larvae and post-larvae were preserved for otolith analysis.

\section{Growth data and determination of hatching dates}

According to the $\left(\mathrm{L}_{\mathrm{S}}\right)$ study of daily growth, larvae were sorted in length class $(0.5 \mathrm{~mm})$ and classified according to the following categories: 'larvae' if the standard length $\left(\mathrm{L}_{\mathrm{S}}\right.$ )was less than $10 \mathrm{~mm}$, post-larvae if $\mathrm{L}_{\mathrm{S}}$ was between $11-30 \mathrm{~mm}$, juvenile if $\mathrm{L}_{\mathrm{S}}$ was between 31-150 $\mathrm{mm}$ and pre-recruits if $\mathrm{L}_{\mathrm{S}}$ was larger than $150 \mathrm{~mm}$ (SEAMAR, 2002).

For the analysis of growth data, a sub-sample of larvae and post-larvae from each length class and area were taken from each survey (SM04 and SM05). Otolith samples for mackerel juveniles and pre-recruits were obtained from the commercial purse seine fleet and from the bottom trawl survey from July to October 2000. The microstructure analysis was obtained from 313 larval, 64 post-larval and 68 juvenilepre-recruit otoliths, following the procedure described in Villamor et al. (2004b). Age 
was estimated by interpreting and counting daily growth rings on otoliths (sagittae). Methodological ageing procedures described in Secor et al. (1992), Migoya (1989) and D'Amours et al. (1990) were followed and an age length key was elaborated by survey and total.

To determine age structure of mackerel larvae and post-larvae catches, age keys were applied to the length distributions of larvae-post-larvae catches obtained by station and survey.

The frequency distribution of hatching dates (birthdate distributions) of each category was obtained by subtracting the calculated age (days) from the sampling date (Campana and Jones, 1992).

\section{Oceanographic and meteorological external data}

Some external data sources were taken to support the analysis either for the SEAMAR cruises in 2000 and for the 10-years recruitment timeseries. Large-scale atmospheric surface level pressure and wind fields were taken from the NCEP Reanalysis, provided by the NOAA-CIRES Climate Diagnostics Cente (Kalnay et al., 1996). Local series of wind data at coastal observatories in Santander and near Peñas Cape (Fig. 3) were provided by the Spanish Meteorological Agency (www.aemet.es).

Surface currents and meteorological parameters at four points in the north-west and north slope were obtained from buoys of the "Deep Water Network" (DWN), operated by the Spanish Port Authority (Alvarez-Fanjul et al., 2003). These buoys are moored on the continental slope over a depth about 400m (Fig. 3). Currents are measured with an Aandera UCM-60 acoustic current meter placed at 3m depth. The wind anemometer at the buoy is at $3 \mathrm{~m}$ height.

Surface Ekman transport induced by wind stress is regularly computed from geostrophic winds provided by the Spanish Meteorological Agency in a $1^{\mathrm{o}} \times 1^{\mathrm{o}}$ control 
1

2

3

4

5

6

7

8

9

10

11

12

13

14

15

16

17

18

19

20

21

22

23

24

25

26

27

28

29

30

31

32

33

34

35

36

37

38

39

40

41

42

43

44

45

46

47

48

49

50

51

52

53

54

55

56

57

58

59

60

cell centred at $43^{\circ} \mathrm{N} 11^{\circ} \mathrm{W}$ (Fig. 3; see Lavín et al., 1991 or Cabanas and Alvarez, 2005, for a review). The eastward transport calculated as $Q_{x}=\tau_{y} /(f \rho)\left(\mathrm{m}^{3} \mathrm{~s}^{-1} \mathrm{~km}^{-1}\right)$, where $\tau_{y}$ is the north-south wind stress, $f$ the Coriolis factor and $\rho$ the density of seawater, provides a measure of the upwelling/downwelling intensity at the Atlantic Iberian margin, with strong effect in the circulation pattern into the Bay of Biscay. 


\section{RESULTS}

\section{Meteorology and hydrography}

The first SEAMAR cruise (SM04) was preceded by an anomalous calm period which began in mid-February and spanned all March, in April $3^{\text {rd }}$ after the cruise had covered about half of the sampling, a severe storm with northern winds which lasted about 2 days occurred. (Fig. 4a, hereafter this storm is referred as S1). The cruise continued under relatively wintry conditions until its end. In late April 2000, between the two SEAMAR cruises, there was a period of various consecutive days of intense and persistent southwesterly winds (Fig. 4b, hereafter storm S2). These two different meteorological situations are both very common in the Bay of Biscay, the southwestern gales typically occur in autumn-winter and tend to last several days while northern gales are common in wintertime and are usually shorter.

The effects of these storms had different consequences in the oceanographic structure which can be inferred at a first glance from the subinertial surface current series from the DWN buoys (Fig. 4c, d).

S1 caused a peak of southward current which rapidly evolved clockwise as the storm passed by. The intensity of currents was low-to-average compared with the mean absolute current velocity. On the other hand, S2 caused the development of a warm and saline water intrusion along the north Spanish shelf that implied a severe shift on the oceanographic conditions. The effect of this particular event in the oceanography at the Bay of Biscay is described in Gonzalez-Pola et al. (2005) but a rough description is as follows; S2 was characterised by strong SW winds, associated to downwelling conditions, mainly at the western part of the Bay of Biscay and much less evident at the inner part. However, surface currents were relatively low at the Vigo latitude (Silleiro Buoy, around $10 \mathrm{~cm} / \mathrm{s}$ ), increasing at Villano to $\sim 20 \mathrm{~cm} / \mathrm{s}$ and gaining intensity and persistence downstream (eastwards) at Estaca and Peñas $(\sim 30 \mathrm{~cm} / \mathrm{s})$, always directed 
along the shelf-break with a subtle veering inshore (Fig. 4d). This downstream current enhancement evidenced a strong dependence of Cantabrian Sea shelf-slope circulation on remote forcing, specifically on downwelling favourable Ekman transport west of Galicia. As accurately depicted in SM05 sampling, a saline and warm water intrusion of southern origin was developed in the Ortegal area, extending to eastward until approximately $6^{\circ} \mathrm{W}$ Longitude (Fig. 5a, b). This intrusion occupied the whole shelf and partially the slope with extreme differences of $1{ }^{\circ} \mathrm{C}$ and 0.1 in salinity with respect to the SM04 configuration. The geopotential anomaly at the Ortegal Grid turned from a meridional low activity arrangement to a zonal high activity one and geostrophic current increased mainly at the shelf-edge slope, where an oceanic front with meandering patterns was established (not shown). The new advected waters had not only a strong signature in physical properties (higher salinity and temperature and lower density) but also in biological ones (see also section below), which also can serve to delimit the front. For instance clorophyll-fluorescence signal was lower in the area covered by the intrusion (Fig. 5c, d), as expected from waters advected from a southern origin (Alvarez-Salgado et al., 2003).

\section{Zooplankton biomass}

Mesozooplankton dry weight biomass (DWB) during the SEAMAR cruises is shown in Fig. 5e, f. The first sampling period in SM04 begins just after the spring entrance, coinciding with the beginning of the seasonal warming of the surface layers and the start of the spring phytoplankton bloom. Spatial distribution of zooplankton abundance and DWB is characterised by a cross-shelf trend following a well established ecological pattern. Three distinguished abundance areas can be outlined, the continental shelf along Galicia an into the Bay of Biscay until central Cantabrian Sea presents high DWB 
content, an intermediate abundance region surrounds this area and a patch of low abundance is present at the inner Bay of Biscay.

During the second sampling period SM05, the water column showed an incipient thermocline at 20-25 m depth with phytoplankton concentrated at a subsurface maximum just below the thermocline (results not shown). The main patches of zooplankton DWB were found in the central Cantabrian Sea and also high values were found off the shelf break.

In addition to the cross-shelf pattern, an along-shelf pattern can also be outlined. The increase in plankton DWB is observed first in the western side of the Cantabrian Sea, progressing eastwards with the season. Topography also seems to play a role in retaining or enhancing the growth of plankton populations, as the main concentrations encompass the major capes along the Cantabrian coast and it is also apparent a relationship with the hydrographical pattern, especially near the newly developed frontal zone. The patchy structure (partially smoothed by objective analysis in the representation) is reflected in the wide range of values of DWB within the same survey (typical values ranging from 2 to $30 \mathrm{mg} \mathrm{DWB} \mathrm{m}^{-3}$ ). Nevertheless, mean values of mesozooplankton DWB in shelf waters (0-200 m depth) during the mackerel larval season (mid-March to mid-May) along the north Spanish coast do not show large differences.

\section{Distribution and abundance of mackerel eggs and larvae}

In SM04 the highest abundance of eggs was found in the areas of the Cantabrian Sea and Vizcaya and always over the continental shelf. In SM05, eggs were found more widespread throughout the study area, both over and off the continental shelf, even at oceanic stations over $4500 \mathrm{~m}$ depth. The highest egg concentrations were found in the area of Ortegal (Fig. 6a, c). 
During the surveys, a total of 916 and 988 mackerel larvae were caught with the Bongo net respectively in SM04 and SM05. Distribution and abundance are shown together with the size distribution in Fig. 6b, $d$ (see section below for results on size distribution). In SM04 most of the larvae were found in the Ortegal area, mainly over the continental shelf (Fig. 6b) while very few larvae were caught off the Galician coast. The concentration of mackerel larvae decreased towards the east, with the exception of an isolated patch of young larvae (165 larvae $/ \mathrm{m}^{2}, 35 \%$ of the total mackerel larvae sampled) found nearly at the end of the cruise at a single station close to the coast in the central-east Cantabrian area. Most of the larvae were found over the shelf. In SM05 (Fig. 6d), the greater abundance of mackerel larvae were found in the inner Bay of Biscay, both over and off the shelf. In the Ortegal area, larvae were found only over the continental shelf. As in SM04, no larvae were found in waters west of Galicia.

In summary, eggs and larvae were located near the shelf edge, both onshore and offshore. The eggs were more widespread distributed, moving away from the shelf, during the second cruise. During the first cruise more abundant patches of larvae were found in the western area whereas in the second the higher frequency was found in the eastern part.

\section{Larval size and age distributions}

In SM04, 46\% of all larvae were smaller than $3.9 \mathrm{~mm}$ [the $\mathrm{L}_{\mathrm{S}}$ of newly-hatched Atlantic mackerel larvae averaged $3.59 \mathrm{~mm}$ (Mendiola et al., 2007)] and 7\% were were larger than $10 \mathrm{~mm}$. The most abundant and the largest larvae were found in the Ortegal area. In SM05, the total abundance of mackerel larvae was slightly higher, but they were smaller in size, with $70 \%$ of the larvae being smaller than $3.9 \mathrm{~mm}$. Most of the mackerel larvae (including the smallest ones) were found in the inner part of the Bay of Biscay, either offshore and in coastal waters. 
Distribution by age differed between the two surveys (Fig. 6b, d). In SM04, the youngest larvae $(<10$ days) were mainly concentrated at the aforementioned station near the coast in the central part of the Cantabrian Sea made at the end of the cruise. Larvae aged 10-20 and 20-30 days were most abundant, and larvae as old as 30 days were found in the Ortegal area (these were the oldest found in the 2000 surveys). Actually these older larvae were collected at the beginning of the cruise. In SM05, larvae of 10 to 20 days was the most abundant age group, which were distributed along the Cantabrian coast. Very few larvae older than 20 days were caught $(6 \%)$.

In summary, larval distribution by age shows some differences in the two consecutive surveys. Counter intuitively, older (larger) larvae were found in the first survey, while only younger (smaller) larvae were found in the second one. The spatial distribution of age-classified larvae also changed between the two cruises. In the first survey, abundant patches of older larvae were found in the western area, while less abundant patches of young larvae were found in the east. In the second survey, only young larvae were found, and the area of highest larval abundance was the eastern area, with low abundance patches in the west.

\section{Birthdate Distributions}

The microstructure of larval $(n=313)$ and postlarval $(n=64)$ otoliths from both cruises was analysed. Fresh standard length of the mackerel larvae used in the otolith analyses ranged from 2.3-10.9 $\mathrm{mm}$ (ages from 7 to 36 days), whereas the mackerel postlarvae ranged from 11.3-23.7 mm (ages from 24 to 38 days). Data by area are shown in Tables 1 and 2.

Back-calculated hatching period was estimated from juveniles and pre-recruits caught from July to October 2000. Total of 68 otoliths were analysed (SL ranged from 
121 to $202 \mathrm{~mm}$ with back-calculated hatching period between 65 and 186 days). (Table 3)

The back-calculated hatching period estimated by category was between February $26^{\text {th }}$ and May $3^{\text {rd }}$ for the larvae, (mean hatching date of March $28^{\text {th }} \pm 20$ days), between February $24^{\text {th }}$ and March $16^{\text {th }}$ for post-larvae (mean date of March $3^{\text {rd }} \pm 4$ days), and between April $5^{\text {th }}$ and May $23^{\text {rd }}$ for juveniles and pre-recruits (mean date May $7^{\text {th }} \pm 11$ days). (Fig. 7)

Figure 7 provides the retro-calculated hatching date for larvae and post-larvae from SEAMAR cruises and for juvenile and pre-recruits together with wind speed cubed at Santander observatory from Spanish Meteorological Agency (the rationale of choosing this local wind-speed time series as valid indicative of the Cantabrian Sea are discussed in the next section). The sequence of calm periods and wintry events interposed are evident. Both storms S1 and S2 present sustained wind over force 6 in this local record though we actually know that S2 did not caused so widespread turbulence record in the Cantabrian Sea. The older (larger) larval cohort -i.e. the postlarvae- , found at the beginning of the initial survey SM04 in the Ortegal area, was born around March $1^{\text {st }}$ during a calm period, well before S1. After S1 and within the same cruise SM04, groups of young larvae were found towards the east, indicating some survival after the first storm. During the second cruise SM05 no larvae from early spawning (large) were found but only young specimens. The later birthdate analysis of up to 68 juveniles (i.e. survivors) did not find a single one which had born before the first storm S1, thus indicating almost the non-existence of survivors from the cohorts born in early spring, and only a few surviving juveniles born prior to the second storm S2 (about $10 \%)$. 


\section{DISCUSSION}

The case study analysed in this work refers to one of the largest recruitment failures for mackerel in the available time series. As stated in the introduction, identification of potential causes of recruitment failure in specific may allow to construct hypothesis on factors controlling recruitment, both for theoretical and numerical (simulation) studies. In the present discussion we exploit the outcomes generated in the so particular year 2000 in order to attempt to isolate the cause of strong mortality that occurred that year in mackerel recruitment, and the conclusion of this analysis are then discussed in a broader early life stages mortality context.

\section{Causes of mackerel recruitment failure in 2000}

As previously presented, the 2000 year class provides one of the lower recruitment abundance of the available time series for NEA mackerel. Meteorological conditions in 2000 were characterized by the passing of the two different storms S1 and S2, after a relatively mild end of winter. Obviously both storms were accompanied with strong winds in the area of mackerel nursery, though S2 effect was attenuated at Central Cantabrian Sea. Besides that, the storm S2 caused a strong advection of shelf-slope waters and the development of a large intrusion that became evident during the SM05 sampling. Actually, as the key period for mackerel spawning coincides with the spring transition, the alternations of strong winds and calmly insolate antycliclonic weather is a common pattern, though each year present its particular sequence.

Strong winds like those present in both S1 and S2 have two important effects against successful larval development and recruitment. Firstly, the wind acting directly over the sea surface induces the breaking of the stratification to produce a mixing layer. The rate at which turbulent kinetic energy of the wind is added to the upper ocean is proportional to the third power of the wind speed (e.g. Husby and Nelson, 1982, as 
represented in Figure 7. Turbulent mixing may disrupt food aggregations at the subsurface chlorophyll maximum and may affect the vertical distribution of the eggs, larvae and juveniles of some species, leading to higher rates of mortality (Lasker, 1975, 1978; Mackenzie, 2000). On the other hand persistent wind enhances currents; the transport of the larvae from the area is also a mechanism capable of interrupting periods of larval production (Norcross and Shaw, 1984). As we have seen, in this case S1 was not able to cause a great advection of water whereas S2 produced an important eastward advection throughout the shelf-slope and may well have carried larvae towards unfavourable areas, even offshore.

In agreement with these ideas, periods of strong winds have been related to the failure of larval survival of some species, for example the anchovy of California (Engraulis mordax), the Atlantic menhaden (Breboortia tyrannus), the Atlantic herring (Clupea harengus) and the codfish of Alaska (Theragra chalcogramma) (Peterman and Bradford, 1987; Heath, 1989; Maillet and Checkley, 1991; Bailey and Macklin, 1994). Nevertheless, definitive evidences that relate larval survival and wind conditions are still lacking (MacKenzie, 2000).

Though it would very interesting to get a unique measure of overall wind turbulence in the mackerel larvae habitat, this gauge is not straightforward in a wide area such as the Cantabrian Sea. Local wind records are biased by land topography and present lack of coherence along the coastline, even among stations not too far apart (Otero and Ruiz-Villarreal, 2008), while reanalysis products provide average values for wide cells smoothing the wind field local variability. From the several sources previously presented, coastal observatories are the lengthiest and most robust uninterrupted series of local wind and DWN buoys provide a very interesting record at the shelf-break, but they present some periods of malfunction (gaps), especially at the beginning of the series. 
As storms at this latitude evolve eastward from the west, records of strong winds in the Eastern Cantabrian Sea roughly indicate that all the area have been more or less under the influence of a gale. As previously pointed gales from the north as $\mathrm{S} 1$ are felt all along the Cantabrian Sea shelf where there is no land protection and gales from the SW as S2 are soften while progressing into the Bay of Biscay though subjected to local effects. Particularly over the central Cantabrian Sea shelf SW winds gets partially damped by a near-shore mountains chain. Therefore we have used as a first proxy a local wind record from the Santander coastal observatory (eastern Cantabrian Sea) as indicative of the Cantabrian Sea meteorological state, but we must keep in mind the considerations about sea surface wind anisotropy, stated in the paragraph above.

Figure 7 provided a perspective that helps to analyze the larval size-distribution figure 6 . Though neither of the storms directly eliminated the bulk larvae population, it should be noted that no larvae born before the first storm were caught after the second storm, so somehow the larvae surviving the first storm failed to survive the second. We should point that when sampling with the plankton net, fish of over $38 \mathrm{~mm}$ (early spawned fish, or faster growing fish) are not available to the sampler (maximum size of fish caught), so the proportion of late spawned fish in the plankton samples may have been greater than it is for the whole population of 0 -yr fish. Nevertheless, when juvenile mackerel were collected with purse-seine and trawl gears, the smallest fish caught were $119 \mathrm{~mm}$ long. Thus the proportion of early spawned or faster growing fish should have been greater in the purse-seine hauls than it is in the whole population of 0 -yr fish so we can conclude that large post-larvae from early spawns actually did not survive.

It is remarkable that there were collected almost no specimens, neither larvae nor post-larvae nor juveniles, born while S1 was taking place around March $1^{\text {st }}$. Therefore, it seems clear that the widespread strong turbulence during this storm 
produced the immediate dying of any larvae hatched right at this period, or eggs failed to hatch.

From these results it appears that strong turbulence events seem to prevent the birth of mackerel larvae but do not directly kill existing cohorts, although it is likely that they can damage their health condition. The results obtained in this study suggest that larval survival was highest for the individuals born at the beginning of May 2000 . Assuming a mean incubation period of seven days (Sette, 1943; Lockwood et al., 1977; Mendiola et al., 2007), we obtain April $30^{\text {th }}$ as the mean spawning date of mackerel survivors (juveniles) corresponding to the eggs spawned during the second survey just after the relaxing of the SW winds event and coinciding with a period of low turbulence (calm weather). This is consistent with the hypothesis discussed at the beginning of the section that stability of the upper water column influences recruitment as the firstfeeding larvae require adequate food supplies and certain stability in the water masses for growth and survival.

Limitations in the availability of food and predation are believed to be the main causes of mortality in the larval stages and, as a direct result, in the recruitment that follows (Cushing, 1981 and 1990; Bailey and Houde, 1989). Nevertheless, the direct influence the availability of food has on larval mortality is only evident at very low prey levels (Cushing, 1981), whereas its most important influence has its origin in the limits to larval growth. Fast growth in fish larvae seems to have greater importance in reducing mortality, either by reducing direct vulnerability to predation (Bailey and Houde, 1989; Leggett and Deblois, 1994) or in order to minimize cumulative mortality until recruitment (Chambers and Leggett, 1987). In the study area, the mackerel mortality rate was estimated to be 0.24 day $^{-1}( \pm 0.02)$ in 2000 , similar to other mortality values obtained for this species within other SEAMAR project studies (SEAMAR, 2002) and in agreement with the literature (Houde and Zastrow 1993). Mean values of 
mesozooplankton DW biomass during the mackerel larval season (mid-March to midMay) along the north Spanish coast do not show large differences among 1998, 2000 and 2001 (SEAMAR, 2002) and so food availability in 2000 did not differ from that of other years. Nevertheless, fast growth in the mackerel larval stage gave rise to a high potential for survival in 2000 in the study area, as described in Villamor et al. (2004b).

The starvation of the larvae is the major cause of mortality in some populations (Lasker, 1981), since the skill to locate, to capture and to consume the preys is crucial for its survival and the success of the resultant recruitment (Fuiman and Higgs, 1997). The values of the zooplankton abundance in the Cantabrian Sea seem to be sufficient in order that the larvae of mackerel were not suffering from starvation in the spring of 2000 (Villamor, 2007). Therefore, probably the low larval survival of mackerel was not caused by the food limitation. Coombs et al. (1992) observed that the eggs and larvae of sprat (Sprattus sprattus) and its preys of zooplankton were more dispersed and deep when water masses were more mixed. Nevertheless, Mullin et al. (1985) indicated that moderate episodes of mixing of water masses were not breaking the concentrations of the preys of larvae of anchovy, but they were dispersing these. Olla and Davis (1990) realized experiments with larvae of walleye pollock (Theragra chalcogramma) in captivity, and observed that they were avoiding the turbulence. This behavior of the larvae related to the turbulence can have a big effect on their feeding rate, as the intensity of light decreases at greater depths and therefore reduces the ability of larvae to locate and capture prey (Heath, 1989).

However, the complete failure in recruitment of mackerel larvae from early spring spawns, and especially those from the Ortegal post-larvae cohort, allow an additional explanation related to larval transport. This cohort, when sampled by the end of March previous to S1 were quite abundant and apparently in an advantageous situation to be recruited, however from the later juvenile analysis it seems that the 
cohort was almost annihilated. They were precisely at the waters that were later swept away by the intrusion caused by $\mathrm{S} 2$, replacing the area with new advected waters where only few young larvae were found. Shelf currents mainly develop along-shelf so this cohort was likely advected mainly eastward over the shelf, however the intrusion also generated an oceanic front with meandering patterns at the shelf break that favoured shelf-ocean water interchanges and enhanced mesoescale activity in general. The precise mechanism that prevented the early spring mackerel larvae to get recruited can not be directly inferred but it seems linked to the intrusion, the larvae may have been advected towards unfavourable areas or just they were not able to thrive embedded within a strong current. In the study area, Sanchez and Gil (2000) related weak recruitments of hake (Merluccius merluccius) with years in which the water intrusion (Iberian Poleward Current) was very intense. This produced an increase of the mortality of the larval phases, having been transported towards the oceanic waters.

The location of the major concentrations of larvae (in Ortegal and in the Cantabrian during the first and second surveys respectively) support the known pattern about spawning of the mackerel in the southern area, which takes place in January to the west of Portugal and moves progressively in the time towards the northwest of Galicia and the east of the Cantabrian Sea (ICES, 2002b; 2005). Mackerel spawning in the southern area lasts from January to June, with a spawning peak in January/February in Portuguese waters (Jorge et al., 1982) and in April in the south of the Bay of Biscay, Division VIIIc (Solá et al., 1990). From 1998 to 2004 the annual maximum of the eggs production takes place since March to middle of May, with a peak in April in 19982001, and in March in 2004 (ICES, 1999; 2002b; 2005). However, in 2007, the egg production curves for mackerel in the southern area show a high density of eggs in March, while a very low production was estimated in the other periods (ICES, 2008c). Change in the timing of the spawning migration to the southern area of mackerel has 
been detected in recent years (Punzón and Villamor, 2009) and there are also signs of a shift of the spawning peak of mackerel in 2004, but especially in 2007. This means that the result of the distribution of hatch dates of the survivors in 2000 is in agreement with the data observed and described in the literature. The outcome observed in this study where the juvenile survivors were born in April and May 2000 confirms that the recruits of mackerel in the north and northwest of the Iberian Peninsula come from the spawning that the adults perform in the Cantabrian Sea during the spring. In addition, the findings of Uriarte et al. (2001) from tagging studies of juvenile mackerel indicated that these fish did not tend to move away from the nursery areas prior to recruitment to the adult stock after approximately three years. Also our study show that not all eggs releases have the same fate, and only those released in a given period (April-May 2000) are the ones responsible for the recruitment of that year.

\section{Long-term mackerel recruitment and environmental conditions}

We will now explore the long-term mackerel recruitment series in relation to the occurrence of strong-wind events, particularly about April (peak of the mackerel spawning in the study area). The environmental conditions in the periods of prespawning and spawning can affect the success of recruitment of the mackerel. Borja et al. (2002) showed a good correlation between the turbulence in April and the recruitment. The series of recruitment of mackerel (ICES, 2008b) shows that a great variability exists in the North East Atlantic, and the recruitment in the southern area roughly reflects the same overall pattern.

As we have seen in the case of spring 2000, the response of the oceanographic system to a storm is highly dependent on its bearing, strength and duration and many configurations may arise after it passes away. Typically, continental shelves are slender and along-shelf currents are established more easily than across-shelf currents, though 
the later are critical for larvae success of most species that can not survive off the shelf (Epifanio and Garvine, 2001). The effect produced in the Cantabrian Sea oceanographic system by the two types of storms in spring 2000 are the standard expected responses for such kind of forcings, i.e., shelf across-shelf winds do not cause strong surface currents while along-shelf winds do so, enabling durable upwelling/downwelling geostrophically balanced configurations. Besides that, some observations suggest that remote forcing at the Atlantic margin favour the development of strong shelf-slope currents even though the Cantabrian Sea were not hit by strong winds (Pingree and Le Cann, 1990; Gonzalez-Pola et al., 2005). However, actual storms from the west tend to roll from southwest to northwest as they pass and affect more or less the whole area so it is not easy to disengage the causality of each term.

While it is not easy to isolate the effect of turbulence alone from that of advection alone as the cause of a recruitment failure case, we can consider separately the wind speed cubed at the Cantabrian Sea (turbulent kinetic energy added to the water column) and the downwelling favourable Ekman transport west of Galicia (a trigger for shelf currents causing advection of southern origin waters). Figure 8 represents this pair of mechanisms together with the mackerel recruitment index achieved in the following year (1998-2008). Avoiding any attempt of establishing a numerical correlation, some connections appear between environmental conditions, forcing agents and recruitment success. Years 1998, 2000 and 2004 present strong local wind events recorded in April, well over Beaufort 6, and all present very low recruitment indexes. Year 2003 also presents very low recruitment while local wind events are medium, but this year Ekman transport index along April, with two strong peaks, was favourable to the development of strong intrusions at the Cantabrian Sea. Other years except 2000 and 2003 strong Ekman transport pulses only appeared about the first of April $(1998,1999)$ or before $(2001,2002,2005,2006)$ or there were none since early March. 
On the other hand, years of absence of either strong Ekman transport pulses or local wind pulses as 2007, 2006 and 2002 showed very high recruitment indexes, including the 2002 maximum record. Average years in both forcing agents show some diversity in the recruitment success, years 1999 and 2005 presented local wind events about Beaufort 6 and moderate Ekman pulses at the beginning of May, and they presented good and medium recruitment respectively. Year 2001 with a short local wind peak at the beginning of April yielded a medium to low recruitment index.

In summary, years with either strong local wind events record or Ekman transport pulses around April present very low recruitment while years of absence this pair of mechanisms showed very high recruitment indexes. In the case of the extreme failure of year 2000 both were present. Year 2003 is very interesting, contrary to the case of spring 2000 April winds were not too hard, but equally to that year it showed a particularly calmly conditions during March. Furthermore, the strong shelf current and warm waters advection that had been detected in December 2002 progressing into the Bay of Biscay had actually vanished by early spring (Ruiz-Villareal et al., 2006). Like in year 2000 relevant downwelling conditions re-appeared in April 2003. Therefore, year 2003 recruitment failure supports the idea of advection and strong shelf-slope currents caused by April downwelling pulses and as an additional cause of early spring 2000 spawns lack of success.

As described earlier, many documents exist relating wind events and recruitment. This way, Cury and Roy (1989) and Roy et al. (1995) indicated that the environmental factors associated with the wind (for example, turbulence, upwelling and transport) have significant impacts in the recruitment of the fish. Lasker et al. (1978) suggested unusual storms during the winter might affect negatively the recruitment of the anchovy of California. The results of Maillet and Checkley (1991) indicated that the duration, intensity and frequency of storms during the spawning season of the 
menhaden in North Carolina are determinant in the rate of larval growth and in the success of the recruitment. Nevertheless, in other cases with long temporal series as the Pacific sardine (Butler, 1991) and the anchovy of the Bay of Biscay (Borja et al., 1998; Allain et al., 2001), they could not have established an environmental clear conditions that predict the intensity of the recruitment (Planque and Buffaz, 2008). Our work illustrates why overall relationships with aggregated indexes generally fail. Integrated measures do not have the spatio-temporal precision to properly account for the kind of failures shown in this work.

All in all, mackerel is a serial spawner (Macer, 1976). This spawning strategy could be interpreted as an adaptation to an unpredictable environmental factor. The mature fishes spawn partially throughout the spawning season, ensuring that at least some eggs and larvae are present when an optimal environmental window occurs (Cury and Roy, 1989) and survive to be recruited. 


\section{CONCLUSIONS}

Our results indicate that the survival of Northeast Atlantic mackerel larvae in the Southern area may be explained by environmental variables and that the strength of recruitment is affected. Both strong wind and advection can cause a failure in recruitment; both together can cause a massive lost.

The study described in this paper demonstrates the great usefulness of the analyses of the otolith microstructure to know the processes that intervene in the recruitment of the annual classes and the great interest that has the description of the oceanographic conditions for the knowledge of the pelagic ecosystem. The continuing of monitoring is needed to asses more cases of recruitment failure and success. IBM models could benefit from this study.

On the other hand, part of the mechanisms that unleash these processes and his performance in diverse stages of the vital cycle (as for example between the post-larval and juvenile stage) remain still unknown. 


\section{ACKNOWLEDGEMENTS}

This SEAMAR project (FAIR CT98-3695) was funded through the Commission of the European Communities, Comisión Interministerial de Ciencia y Tecnología (Spain, EC 97/0097), and Instituto Español de Oceanografía. We acknowledge the institutions that have provided the essential external data that have allowed the interpretation of the results, Spanish Port Authorities, the NOAA-CIRES Climate Diagnostics Center and the Spanish Meteorological Agency. We would also like to thank all those who helped with this project, particularly the crew of the different oceanographic surveys on board RV Cornide de Saavedra and Thalassa and especially to Joaquín Barrado for his assistance in the preparation of otolith samples. Thanks to Clara Dueñas and Charo Navarro by reading the otoliths of mackerel from the acoustic surveys. 


\section{REFERENCES}

Allain, G., Petitgas, P. and Lazure, P. (2001) The influence of mesoscale ocean processes on anchovy (Engraulis encrasicolus) recruitment in the Bay of Biscay estimated with a three-dimensional hydrodinamic model. Fish. Oceanogr. 10 (2): 151-163.

Alvarez-Fanjul, E., Alfonso M., Ruiz M. I., López J. D., and Rodriguez I. (2003) The Deep Water Network. In: Building the European Capacity in Operational Oceanography. H. Dahlin (ed.), Elsevier Science Ltd, pp. 398-402.

Alvarez-Salgado, X. A., Figueiras F. G., Perez F. F., Groom S., Nogueira E., Borges A., Chou L., Castro C. G., Moncoiffe G., Rios A. F., Miller A. E. J., Frankignoulle M., Savidge G., and Wollast R.. (2003) The Portugal coastal counter current off NW Spain: new insights on its biogeochemical variability. Prog. Oceanogr., 56(2): 281-321.

Bailey, K.M. and Houde, E.D. (1989) Predation on eggs and larvae of marine fishes and the recruitment problem. Adv. Mar. Biol. 15: 1-83

Bailey, K.M. and Macklin, S.A. (1994) Analysis of patterns in larval walleye pollock Theragra chalcogramma survival and wind mixing events in Shelikof Strait, Gulf of Alaska. Mar. Ecol. Prog. Ser. 113 : 1-12

Bartsch, J. and Coombs, S.H. (2001) An individual-based growth and transport model of the early life-history stages of mackerel (Scomber scombrus) in the eastern North Atlantic. Ecol. Mod. 138: 127-141

Beverton, R.J.H., and Holt, S.J. (1957). On the dynamics of exploited fish populations. Fish. Invest. Ser. 2 Mar. Fish. G.B. Minist. Agric. Fish. Food No. 19, 533 pp 
Borja, A., Uriarte, A., Egaña, J., Motos, L. and Valencia, V. (1998) Relationships between anchovy (Engraulis encrasicolus) recruitment and environment in the Bay of Biscay. Fish. Oceanogr. 7: 375-380.

Borja, A., Uriarte, A. and Egaña, J. (2002) Environmental factors and recruitment of mackerel, Scomber scombrus L. 1758, along the north-east Atlantic coasts of Europe. Fish. Oceanogr. 11: 116-127.

Butler, J.L. (1991) Mortality and recruitment of Pacific sardine, Sardinops sagax caerulea, larvae in the California current. Can. J. Fish. Aquat. Sci. 48: 17131723.

Cabanas, J. M. and Álvarez, I. (2005) Ekman transport patterns in the area close to the Galician coast (NW, Spain). J. Atmos. Ocean Sci. 10(4), 325-341.

Campana, S. and Jones, C. (1992) Analysis of otolith microstructure data. In: Otolith microstructure examination and analysis. D.K. Stevenson and S.E. Campana (eds), Can. Spec. Publ. Fish Aquat. Sci. 117: 73-100.

Chambers, R.C. and Legget,W.C. (1987) Size and age metamorphosis in marine fishes: analysis of laboratory reared winter flounder (Pseudopleuronectes americanus) with a review of variation in other species. Can. J. Fish. Aquat. Sci. 44: 19361947.

Coombs, S.H., Nichols, J.H., Conway, D.V.P., Milligan S. and Halliday, N.C. (1992) Food availability for sprat larvae in the Irish Sea. J. mar. biol. Ass. U.K. 72: 821834.

Cury, P. and Roy, C. (1989) Optimal environmental window and pelagic fish recruitment success in upwelling areas. Can. J. Fish. Aquat. Sci. 46: 670-680. 
Cushing, D.H. (1990) Plankton production and year-class strength in fish populations: an update of the match/mismatch hypothesis. Adv. Mar. Biol. 26: 249-293.

Cushing, R. (1981) Marine ecology and fisheries. Cambridge University Press, 278 pp.

D’Amours, D., Landry, J.G. and Lambert, T.C. (1990) Growth of juvenile (0-Group) Atlantic mackerel (Scomber scombrus) in the Gulf of St. Lawrence. Can. J. Fish. Aquat. Sci. 47: 2212-2218.

Epifanio, C.E. and Garvine, R.W. (2001) Larval transport on the Atlantic Continental Shelf of North America: a Review. Estuar. Coast. and Shelf Sci. 52 (1): $51-77$.

Fuiman, L.A. and Higgs, D. (1997) Ontogeny, growth and the recruitment process. In: Early Life History and Recruitment in Fish Populations. R. C. Chambers \& E.A. Rippel (eds). London: Chapman \& Hall, pp. 225-249.

Gallego, A, North, EW and Petitgas, P. (2007) Introduction: status and future of modelling physical-biological interactions during the early life of fishes. Mar. Ecol. Prog. Ser. 347: 121-126.

Gonzalez-Pola, C., Ruiz-Villarreal, M., Lavin, A., Cabanas, J. M. and Alvarez-Fanjul, E. (2005) A subtropical water intrusion spring-event in the shelf-slope of the south-western Bay of Biscay after strong wind-forcing pulses. J. Atmos. Ocean Sci.. 10(4): 343-359,

Heath, M. (1989) A modelling and field study of grazing by herring larvae. Rapp. P.-v. Réun. Cons. Int. Explor. Mer. 191: 233-247.

Hjort, J. (1914) Fluctuations in the great fisheries of northern Europe reviewed in the light of biological research. Rapp. P-v. Réun. Cons. int. Explor. Mer, 20: 1-228. 
Hjort, J. (1926) Fluctuation in the year classes of important food fishes. J. Cons. Int. Explor. Mer. 1: 1-38.

Houde, E.D. and Zastrow, C.E. (1993) Ecosystem- and taxon- specific dynamic and energetics properties of larval fish assemblages. Bull. Mar. Sci. 53: 290-335.

Husby, D.M. and Nelson, C. S. (1982) Turbulence and vertical stability in the California current. CalCOFI Rep. Vol. XXIII: 113-129.

ICES. (1996) Report of the Working Group on the Assessment of Mackerel, Horse Mackerel, Sardine and Anchovy. ICES CM 1996/Assess: 7, 340 pp.

ICES. (1998) Report of the Planning Group for Pelagic Acoustic surveys in ICES Subareas VIII and IX. ICES CM 1998/G:2, 17 pp.

ICES. (1999) Report of the Working Group on Mackerel and Horse Mackerel Eggs Surveys. ICES CM 1999/G: 5, 83 pp.

ICES. (2000) Report of the Working Group on the Assessment of Mackerel, Horse Mackerel, Sardine and Anchovy. ICES CM 2000/ACFM: 5, 546 pp.

ICES. (2002a) Report of the Planning Group on Aerial and Acoustic Surveys for Mackerel. ICES CM 2002/G:03, 44 pp.

ICES. (2002b) Report of the Working Group on Mackerel and Horse Mackerel Eggs Surveys. ICES CM 2002/G: 6, 102 pp.

ICES. (2005) Report of the Working Group on Mackerel and Horse Mackerel Egg Surveys. ICES CM 2005/G: 09, 83 pp.

ICES. (2008a) Report of the Working Group on Acoustic and Egg Surveys for Sardine and Anchovy in ICES Areas VIII and IX (WGACEGG). ICES CM 2008/LRC:17, 173 pp. 
ICES. (2008b) Report of the Working Group on Widely Distributed Stocks (WGWIDE). ICES CM 2008/ACOM: 13, 674 pp.

ICES. (2008c) Report of the Working Group on Mackerel and Horse Mackerel Egg Surveys. ICES CM 2008/LRC:09, 107 pp.

Iglesias, M., Miquel, J., Villamor, B., Porteiro, C., and Carrera, P. (2005) Spanish Acoustic surveys in Divsion VIIIc and Sub-division IXa North: Results on Mackerel from 2001 to 2005. Working Document to Working Group Mackerel, Horse Mackerel, Sardine and Anchovy, ICES CM 2006/ACFM: 08, 25 pp.

Iles, T.D. and Sinclair, M. (1982) Atlantic herring: stock discreteness and abundance. SCI, 215: 627-633.

Jorge, I.M., Gordo, L.S. and. Martins, M.M (1982) On the sexual maturation and condition factor of Scomber scombrus L. from the occidental coast of Portugal during 1981. ICES C.M. 1982/H: 58, 6 pp.

Kalnay, E., Kanamitsu, M., Kistler, R., Collins, W., Deaven, D., Gandin, L., Iredell, M., Saha, S., White, G., Woollen, J., Zhu, Y., Chelliah, M., Ebisuzaki, W., Higgins, J., Janowiak, W., Mo, K. C., Ropelewski, C., Wang, J., Leetmaa, A., Reynolds, R., Jenne, R. and Joseph. D. (1996) The NCEP/NCAR 40-year reanalysis project, Bull. Am. Meteorol. Soc. 77(3): 437-471.

Koster FW, Schnack D, Mollmann C. (2003) Scientific knowledge of biological processes that are potentially useful in fish stock predictions Sci. Mar. 67 (1): 101-127.

Lago de Lanzós A., Solá, A., Motos L., and Franco. C. (1993) Mackerel (Scomber scombrus L.) egg distribution and stage I egg production estimates in Division VIIIb, c and IXa N in 1988, 1990 and 1992. ICES C.M., 1993/H: 44, 11 pp. 
Lasker, R. (1975) Field criteria for survival of anchovy larvae: the relation between inshore chlorophyll maximum layers and successful first feeding. Fish. Bull. 73: 453-462.

Lasker, R. (1978) The relation between oceanographic conditions and larval anchovy food in the California Current: identification of factors contributing to recruitment failure. Rapp. P.-V. Reun. Cons. Int. Explor. Mer. 173: 212-230.

Lasker, R. (1981) The role of a stable ocean in larval fish survival and subsequent recruitment. In: Marine Fish Larvae: Morphology, Ecology and Relation to Fisheries. R. Lasker (ed.) Seattle: University of Washington Press, pp. 80-87.

Lavín, A., Díaz del Río, G., Cabanas, J. M. and Casas, G. (1991) Afloramiento en el noroeste de la península Ibérica. Indices de afloramiento para el punto $43^{\circ} \mathrm{N} 11^{\circ}$ W. Periodo 1966-1989. Inf. Téc. Inst. Esp. Oceanogr. 91, 40 pp.

Legget, W.C. and Deblois, E. (1994) Recruitment in marine fishes: is it regulated by starvation and predation in the egg and larval stages?. Neth. J. Sea Res. 32: 2536

Lockwood, S.J., Nichols, J.H. and Coombs, S.H. (1977) The development rates of mackerel (Scomber scombrus L.) eggs over a range of temperatures. ICES CM 1977/J: 13, 8 pp.

Macer, C.T. (1976) Observations on the maturity and fecundity of mackerel (Scomber scombrus, L.). ICES CM 1976/H: 6, 7 pp.

Mackenzie, B.R. (2000) Turbulence, larval fish ecology and fisheries recruitment: a review of field studies. Oceanol. Acta. 23: 357-375.

Maillet, G.L. and Checkley, M. (1991). Storm-related variation in the growth rate of otoliths of larval Atlantic menhaden Brevoortia tyrannus: a time series analysis 
of biological and physical variables and implications for larval growth and mortality. Mar. Ecol. Prog. Ser. 79: 1-16.

Marr, J.C. (1956) The "critical period" in the early life history of marine fishes. J. Cons. Int. Explor. Mer. 21: 160-170.

May, R.C. (1974) Larval mortality in marine fishes and the critical period concept. In: The early life history of fish. J.H.S. Blaxter (ed.) Springer, Heidelberg. pp. 3-20.

Mendiola, D., Ibaibarriaga, L., and Alvarez, P. (2007) Thermal effects on growth and time to starvation during the yolk-sac larval period of Atlantic mackerel Scomber scombrus L. J. Fish Biol. 70: 895-910.

Migoya, M.C. (1989) Etude de la crissance des larves de maquereau bleu (Scomber scombrus, L.) dans le Golfe du St. Laurent, a partir de l'examen de la microstructure des otoliths. PhD thesis, University of Québec, 84 pp.

Miller, T.J. (2007) Contribution of individual-based coupled physical-biological models to understanding recruitment in marine fish populations. Mar. Ecol. Prog. Ser. 347: $127-138$

Mullin, M.M., Brooks, E.R., Reid, R.M.H., Napp, J. and Stewart, E.F. (1985) Vertical structure of nearshore plankton off southern California: a storm and a larval fish food web. Fish. Bull. U.S. 83: 151-170.

Myers, R.A. (2001) Stock and recruitment: generalizations about maximum reproductive rate, density dependence, and variability using meta-analytic approaches. ICES J. Mar. Sci. 58 (5): 937-951

Norcross, B. L. and Shaw R.F. (1984) Oceanic and estuarine transport of fish eggs and larvae: a review. Trans. Am. Fish. Soc., 113: 153-165. 
Olla, B. L. and Davis, M.W. (1990) Effects of physical factors on the vertical distribution of larval walleye pollock Theragra chalcogramma under controlled laboratory conditons. Mar. Ecol. Prog. Ser. 63: 105-112.

Otero, P. and Ruiz-Villarreal M. (2008) Wind forcing of the coastal circulation off north and northwest Iberia: Comparison of atmospheric models. J. Geophys. Res., 113, C10019, doi:10.1029/2008JC004740

Parrish, R.H., Nelson, C.S. and Bakun, A.(1981) Transport mechanisms and reproductive success of fishes in the California Current. Biol. Oceanogr. 1: 175203.

Paulik, G.J. (1973) Studies of the possible form of the stock-recruitment curve. Rapp.P.-V. Réun.CIEM, 164: 302-15

PELASSES. (2002) Direct abundance estimation and distribution of pelagic fish species in north east Atlantic waters. Improving acoustic and daily egg production methods for sardine and anchovy. Study contract No. 99-010. Final report, Brussels: European Commission, DG XIV.

Peterman, M.R. and Bradford, M.J. (1987) Wind speed and mortality rate of a marine fish, the northern anchovy (Engraulis mordax). Sci. 235: 354-356.

Pingree, R. D. and Le Cann, B. (1990) Structure, strength and seasonality of the slope currents in the Bay of Biscay region. J. Mar. Biol. Assoc. U. K. 70(4): 857-885.

Planque, B. and Buffaz, L. (2008) Quantile regression models for fish recruitmentenvironment relationships: four case studies. Mar. Ecol. Prog. Ser. 357: 213223. 
Punzón, A. and Villamor, B. (2009). Does the timing of the spawning migration change for southern component of North East Atlantic Mackerel (Scomber scombrus, L. 1758)? A approximation by the fishery analyses. Cont. Shelf Res. 29: 1195-1204

Roy, C., Porteiro, C. and Cabanas, J.M. (1995) The Optimal Environmental Window Hypothesis in the ICES area: The example of the Iberian sardine. ICES Coop. Res. Rep. 206: 57-65

Ricker, W.E. (1954) Stock and recruitment. J.Fish.Res.Board Can. 11(5): 559-623

Ruiz-Villareal, M., Gonzalez-Pola, C., Diaz del Rio, G., Lavin, A., Otero, P., Piedracoba, S. and Cabanas. J. M. (2006) Oceanographic conditions in North and Northwest Iberia and their influence on the Prestige oil spill. Mar. Pollut. Bull. 53: 220-238.

Sánchez, F. and Gil, J. (2000) Hydrographic mesoscale structures and Poleward Current as a determinant of hake (Merluccius merluccius) recruitment in southern Bay of Biscay. ICES J. Mar. Sci. 57: 152-170.

Secor, D.H., Dean, J.M. and Laban, E.H. (1992) Otolith Removal and Preparation for Microstructural Examination. In: Otolith microstructure examination and analysis. D.K. Stevenson and S.E. Campana (eds). Can. Spec. Publ. Fish Aquat. Sci. 117: 73-100.

SEAMAR. (2002) Shelf-Edge Advection, Mortality and Recruitment. Contract No. CT98-3695, Final Report, May 2002. Brussels: European Commission, DG XIV.

SEFOS. (1997) Shelf Edge Fisheries and Oceanography Study (SEFOS). Project, Contract AIR No. CT93-1105, Final Report, 1997. Brussels: European Commission, DG XIV. 
Sette, O.E. (1943) Biology of the Atlantic mackerel (Scomber scombrus) of North America. Part I: Early life history, including growth, drift and mortality of the egg and larval populations. Fish. Bull. 50: 147-237.

Solá, A., Motos, L., Franco, C., and Lago de Lanzós, A. (1990) Seasonal occurrence of pelagic fish eggs and larvae in the Cantabrian Sea (VIIIc) and Galicia (IXa) from 1987 to 1989. ICES C.M 1990/H: 26, 38 pp.

Torres, R., Barton, E. D., Miller, P., and Fanjul, E. (2003) Spatial patterns of wind and sea surface temperature in the Galician upwelling region. J. Geophys. Res. (C Oceans) 108 C4, 3130, doi:10.1029/2002JC001361,2003

Uriarte, A., Alvarez, P., Iversen, S., Molloy, J., Villamor, B., Martins, M.M. and Myklevoll, S. (2001) Spatial pattern of migration and recruitment of North East Atlantic Mackerel. ICES C.M. 2001/O: 17, 40 pp.

Villamor, B., Abaunza, P., Lucio, P. and Porteiro, C. (1997) Distribution and age structure of mackerel (Scomber scombrus, L.) and horse mackerel (Trachurus trachurus, L.) in the northern coast of Spain, 1989-1994. Sci. Mar. 61(3): 345366.

Villamor, B., Abaunza, P. and Fariña, C. (2004a) Growth variability of mackerel (Scomber scombrus) off North and Northwest Spain and a comparative review of the growth patterns in the Northeast Atlantic. Fish. Res. 69: 107-121.

Villamor, B., Bernal, M. and Hernández, C. (2004b) Models describing Mackerel (Scomber scombrus) early life growth in the North and Northwest of the Iberian Peninsula in 2000. Sci. Mar. 68(4): 571-583. 
Villamor, B. (2007) La caballa (Scomber scombrus, L. 1758) del Atlántico Nordeste: estudio biológico y de la población en aguas del norte y noroeste de la Península Ibérica. $\mathrm{PhD}$ thesis, Universidad de Cantabria, $257 \mathrm{pp}$. 
Table 1. Samples for otolith analysis, range of age and hatching dates of the mackerel larvae, according to geographical area of catch and surveys (SEAMAR 0400 and SEAMAR 0500) in 2000. $\mathrm{L}_{\mathrm{s}}=$ Standard Length $(\mathrm{mm})$, Age $=$ Days, $\mathrm{HD}=$ Hatch date, $\mathrm{SD}=$ Standard Deviation (days). 


\begin{tabular}{|c|c|c|c|c|c|c|c|c|}
\hline \multirow{2}{*}{$\begin{array}{l}\text { Survey, area and } \\
\text { sampling date }\end{array}$} & \multicolumn{2}{|c|}{ Number of Larvae } & \multicolumn{2}{|c|}{$\mathbf{L}_{\mathrm{S}}$ Interval } & \multirow{2}{*}{$\begin{array}{c}\text { Age } \\
\text { range }\end{array}$} & \multicolumn{2}{|c|}{ Hacth date } & \multirow{2}{*}{$\frac{\text { SD }}{\text { days }}$} \\
\hline & sampled & aged & sampled & aged & & range & mean & \\
\hline \multicolumn{9}{|l|}{ SEAMAR 0400} \\
\hline \multicolumn{9}{|l|}{ Galicia } \\
\hline 28-29 March & 5 & 0 & - & - & - & - & - & - \\
\hline \multicolumn{9}{|l|}{ Ortegal } \\
\hline 30 March-2 April & 140 & 86 & $3.8-10.9$ & $4.9-10.9$ & $12-30$ & 2 March-1April & 10 March & 5 \\
\hline \multicolumn{9}{|l|}{ Cantabric } \\
\hline 2-14 April & 99 & 60 & $4.3-10.9$ & $4.3-10.9$ & $16-36$ & 26 Feb-25 March & 10 March & 7 \\
\hline \multicolumn{9}{|l|}{ Biscay } \\
\hline 7-11 April & 31 & 31 & $6.3-10.4$ & $6.3-10.4$ & $15-27$ & 14-26 March & 19 March & 3 \\
\hline Total Area & 275 & 177 & $3.8-10.9$ & $4.3-10.9$ & $12-36$ & 26 Feb-1 April & 12 March & 6 \\
\hline \multicolumn{9}{|l|}{ SEAMAR 0500} \\
\hline \multicolumn{9}{|l|}{ Galicia } \\
\hline 25-28 April & - & - & - & - & - & - & - & - \\
\hline \multicolumn{9}{|l|}{ Ortegal } \\
\hline 29-30 April & 16 & 14 & $3.9-7.1$ & $4.1-7.1$ & $12-24$ & 6-17 April & 12 April & 3 \\
\hline \multicolumn{9}{|l|}{ Cantabric } \\
\hline 1-4 May & 40 & 38 & $2.6-8.1$ & $2.6-8.1$ & $7-32$ & 30 March-27 April & 14 April & 7 \\
\hline \multicolumn{9}{|l|}{ Biscay } \\
\hline 6-13 May & 88 & 84 & $2.3-9.6$ & $2.3-9.6$ & $8-28$ & 8 April-3 May & 21 April & 7 \\
\hline Total Area & 144 & 136 & $2.3-9.6$ & $2.3-9.6$ & $7-32$ & 6 April-3 May & 18 April & 7 \\
\hline \multicolumn{9}{|l|}{ TOTAL } \\
\hline \multicolumn{9}{|l|}{ Galicia } \\
\hline 28 March-28 April & 5 & - & - & & - & - & - & - \\
\hline \multicolumn{9}{|l|}{ Ortegal } \\
\hline 30 March-30 April & 156 & 100 & $3.8-10.9$ & $4.1-10.9$ & $12-30$ & 2 March-17 April & 15 March & 13 \\
\hline \multicolumn{9}{|l|}{ Cantabric } \\
\hline 2 April-4 May & 139 & 98 & $2.6-10.9$ & $2.6-10.9$ & $7-36$ & 25 Feb-27 April & 24 March & 19 \\
\hline \multicolumn{9}{|l|}{ Biscay } \\
\hline 7 April-13 May & 119 & 115 & $2.3-10.4$ & $2.6-10.4$ & $8-28$ & 14 March-3 May & 12 April & 16 \\
\hline Total Area & 419 & 313 & $2.3-10.9$ & $2.6-10.9$ & $7-36$ & 25 Feb-3 May & $28 \mathrm{March}$ & 20 \\
\hline
\end{tabular}


Table 2. Samples for otolith analysis, range of age and hatching dates of the mackerel post-larvae, according to geographical area of catch and surveys (SEAMAR 0400 and SEAMAR 0500) in 2000. $\mathrm{L}_{\mathrm{s}}=$ Standard Length $(\mathrm{mm})$, Age $=$ Days, $\mathrm{HD}=$ Hatch date, $\mathrm{SD}=$ Standard Deviation (days) 


\begin{tabular}{|c|c|c|c|c|c|c|c|c|}
\hline \multirow{2}{*}{$\begin{array}{l}\text { Survey, area and } \\
\text { sampling date }\end{array}$} & \multicolumn{2}{|c|}{ Number of post-larvae } & \multicolumn{2}{|c|}{$\mathbf{L}_{\mathrm{S}}$ interval } & \multirow{2}{*}{$\begin{array}{c}\text { Age } \\
\text { range }\end{array}$} & \multicolumn{2}{|c|}{ Hacth date } & \multirow{2}{*}{$\frac{\text { SD }}{\text { days }}$} \\
\hline & sampled & aged & sampled & aged & & range & mean & \\
\hline \multicolumn{9}{|l|}{ SEAMAR 0400} \\
\hline \multicolumn{9}{|l|}{ Galicia (IXa North) } \\
\hline 28-29 March & - & - & - & - & - & - & - & - \\
\hline \multicolumn{9}{|l|}{ Ortegal (VIIIc West) } \\
\hline 30 March-2 April & 45 & 36 & $11.3-18.1$ & $11.4-18.1$ & $24-38$ & 24 Feb-9 March & 3 March & 2 \\
\hline \multicolumn{9}{|l|}{ Cantabric (VIIIc East) } \\
\hline 2-14 April & 20 & 20 & $11.3-18.2$ & $11.3-18.2$ & $26-36$ & 27 Feb-7 March & 2 March & 3 \\
\hline \multicolumn{9}{|l|}{ Biscay (VIIIc East) } \\
\hline 7-11 April & 7 & 7 & $11.6-23.7$ & $11.6-23.7$ & $25-38$ & 4-16 March & 9 March & 5 \\
\hline Total Area & 72 & 63 & $11.3-23.7$ & $11.3-23.7$ & $24-38$ & 24 Feb-16 March & 3 March & 4 \\
\hline \multicolumn{9}{|l|}{ SEAMAR 0500} \\
\hline \multicolumn{9}{|l|}{ Galicia (IXa North) } \\
\hline 25-28 April & - & - & - & - & - & - & - & - \\
\hline \multicolumn{9}{|l|}{ Ortegal (VIIIc West) } \\
\hline 29-30 April & - & - & - & - & - & - & - & - \\
\hline \multicolumn{9}{|l|}{ Cantabric (VIIIc East) } \\
\hline 01-04 May & - & - & 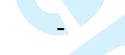 & - & - & - & - & - \\
\hline \multicolumn{9}{|l|}{ Biscay (VIIIc East) } \\
\hline 06-13 May & 3 & 1 & $13.9-38.4$ & 13.9 & 30 & 13 April & - & - \\
\hline Total Area & 3 & 1 & $13.9-38.4$ & 13.9 & 30 & 13-April & - & - \\
\hline
\end{tabular}


Table 3. Samples for otolith analysis, range of age and hatching dates of the juveniles and pre-recruits of mackerel, according to geographical area of catch in $2000 . \mathrm{L}_{\mathrm{s}}=$ Standard Length $(\mathrm{mm})$, Age $=$ Days, $\mathrm{HD}=$ Hatch date, $\mathrm{SD}=$ Standard Deviation (days). 


\begin{tabular}{|c|c|c|c|c|c|c|c|c|}
\hline \multirow{2}{*}{$\begin{array}{c}\text { Area and } \\
\text { Sampling date }\end{array}$} & \multicolumn{2}{|c|}{ Number of juveniles } & \multicolumn{2}{|c|}{$\mathbf{L}_{\mathrm{S}}$ interval } & \multirow{2}{*}{$\begin{array}{c}\text { Age } \\
\text { range }\end{array}$} & \multicolumn{2}{|c|}{ Hacth date } & \multirow{2}{*}{$\frac{\text { SD }}{\text { days }}$} \\
\hline & sampled & aged & sampled & aged & & range & mean & \\
\hline \multicolumn{9}{|c|}{ Biscay (VIIIc East) } \\
\hline 26-27 July & 160 & 28 & $119-161$ & $121-156$ & $65-100$ & 17 April-22 May & 6 May & 9 \\
\hline 26 October & 11 & 2 & $184-207$ & 202-204 & $156-170$ & 9-23 May & 16 May & 10 \\
\hline \multicolumn{9}{|c|}{ Ortegal (VIIIc West) } \\
\hline 8-16 October & 167 & 24 & $183-208$ & $183-202$ & $136-186$ & 5 April-25 May & 7 May & 14 \\
\hline \multicolumn{9}{|l|}{ Galicia (IXa North) } \\
\hline 18 August & 40 & 14 & $158-196$ & $164-194$ & $91-123$ & 17 April-19 May & 6 May & 9 \\
\hline Total & 378 & 68 & $119-208$ & $121-202$ & $65-186$ & 5 April-25 May & 7 May & 11 \\
\hline
\end{tabular}


Figure 1. Location of the study area and ICES Subareas and Divisions in the northeast Atlantic.

Figure 2. Mackerel recruits (proportion of individuals at age-1) from the Spanish Acoustic Survey in ICES Sub-division IXa North and Division VIIIc for the period 1999-2008 (bottom panel). Mackerel recruits (age 0) from the assessment working group report (ICES, 2008b) (uppel panel).

Figure 3. Set of stations performed in the two SEAMAR cruises in spring 2000. The two synoptic areas (Parts) are separated by a black thick line, which also indicates that survey as a whole is not synoptical (see text for explanation). Deep Water Network ocean-meteorological buoys are marked as empty circles. The large-scale representative location for the computation of Ekman Transport is shown as a black asterisk.

Figure 4. Sea Level Pressure and Wind in the North Atlantic from NOAA-CIRES CDC and subinertial surface currents from the DWN Buoys in the two storms S1 and S2. a) S1 (strong N wind event about April 3, 2000). b) S2 (Persistent SW wind event about 18 April, 2000). c) Surface currents induced by S1. Thin circles are the average subinertial current speed from January to July at each buoy and black arrows are the currents at the specific date. d) Surface currents induced by S2. Isobaths of 200 and $1000 \mathrm{~m}$ are marked in $(\mathrm{c}, \mathrm{d})$.

Figure 5. a) Potential temperature field at 75 dbar in SM04. b) Same as (a) in SM05. c) Integrated chlorophyll-fluorescence for the first 60 dbar in SM04; d) Same as (c) in SM05. e) Biomass of mesozooplancton DW $\left(\mathrm{mg} \mathrm{m}^{-3}\right)$ in SM04. f) Same as (e) in SM05. Isobaths of 200 and $1000 \mathrm{~m}$ are marked 
Figure 6. a) Distribution and abundances of mackerel eggs in SM04. b) Distribution and abundances by age class of mackerel larvae-postlarvae in SM04. c) Same as (a) in SM05. d) Same as (b) in SM05.

Figure 7. Birthdate distribution of mackerel larvae, postlarvae and juveniles in 2000 compared to wind speed cubed (turbulent kinetic energy) daily running mean at the Santander coastal observatory from the same year.

Figure 8. Mackerel recruitment index and meteorological forcing from 1998 to 2007. Left panel) Local wind forcing at the Cantabrian Sea represented as wind speed cubed (proportional to turbulent kinetic energy) daily running mean. Thick lines are coastal observatories of Santander and Peñas Cape from Spanish Meteorological Agency and thin line is the Peñas Buoy from Spanish Port Authorities. Vertical ticks are the Beaufort scale. April $1^{\text {st }}$ is marked with a vertical line. Seamar cruises periods are gray shaded. Right panel) Ekman transport at the reference location West of Galicia $-Q_{x}\left(\mathrm{~m}^{3}\right.$ $\mathrm{s}^{-1} \mathrm{~km}^{-1}$ ) as estimation of the East-West upwelling-downwelling strength in northwestern Iberia (downwelling favourable transports are negative). April 1st is marked with a vertical line. Seamar cruises periods are gray shaded. Middle) Mackerel recruitment index (scaled by the line length) as in Figure 3. Note that year 2002 value is more than double of the next high record so two vertical lines appear. 


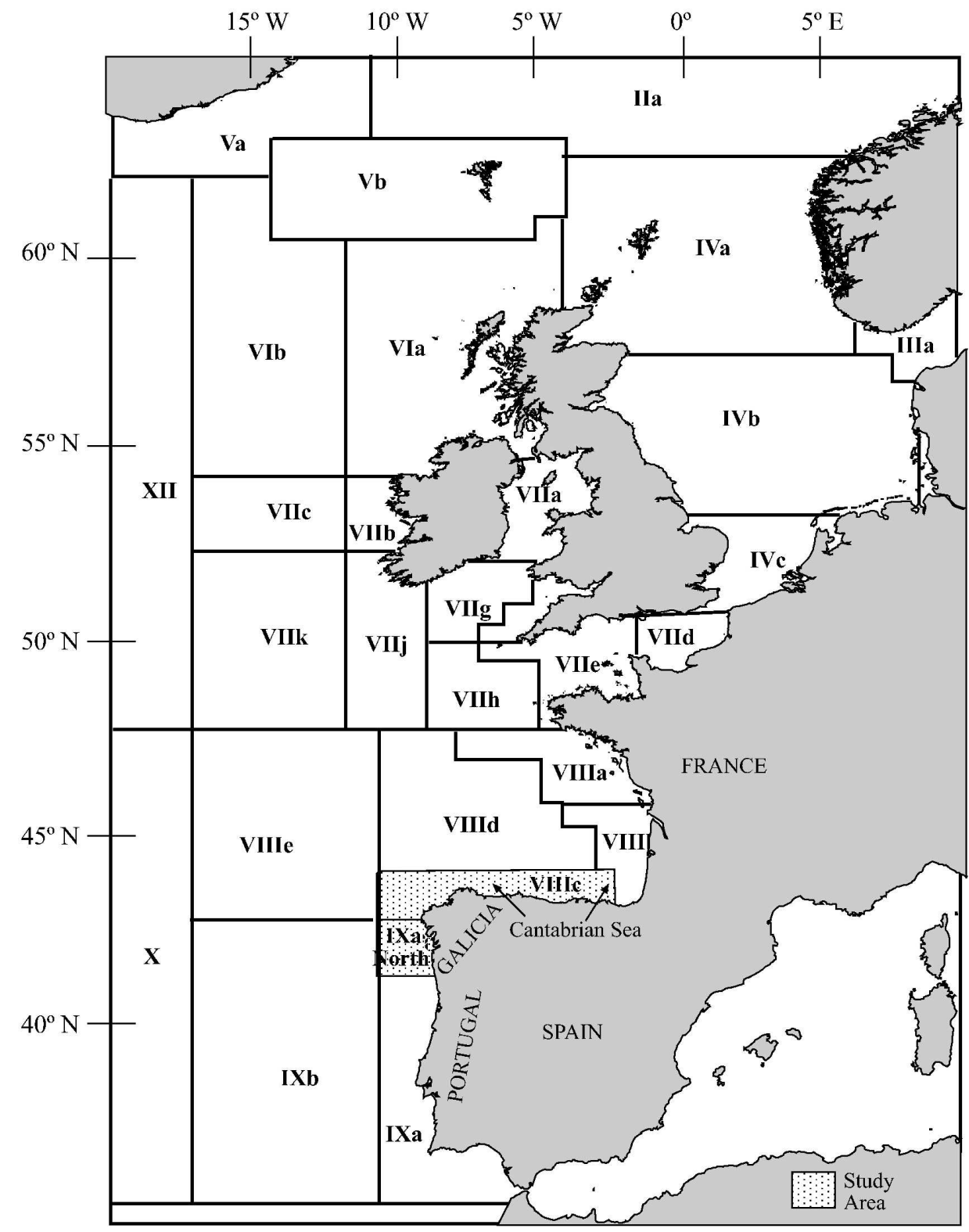

Figure 1. Location of the study area and ICES Subareas and Divisions in the northeast Atlantic. $216 \times 278 \mathrm{~mm}(600 \times 600 \mathrm{DPI})$ 
Figure 2. Mackerel recruits (proportion of individuals at age-1) from the Spanish Acoustic Survey in ICES Sub-division IXa North and Division VIIIc for the period 1999-2008 (bottom panel). Mackerel recruits (age 0) from the assessment working group report (ICES, 2008b) (uppel panel). $200 \times 89 \mathrm{~mm}(600 \times 600 \mathrm{DPI})$ 
Figure 3. Set of stations performed in the two SEAMAR cruises in spring 2000. The two synoptic areas (Parts) are separated by a black thick line, which also indicates that survey as a whole is not synoptical (see text for explanation). Deep Water Network ocean-meteorological buoys are marked as empty circles. The large-scale representative location for the computation of Ekman Transport is shown as a black asterisk.
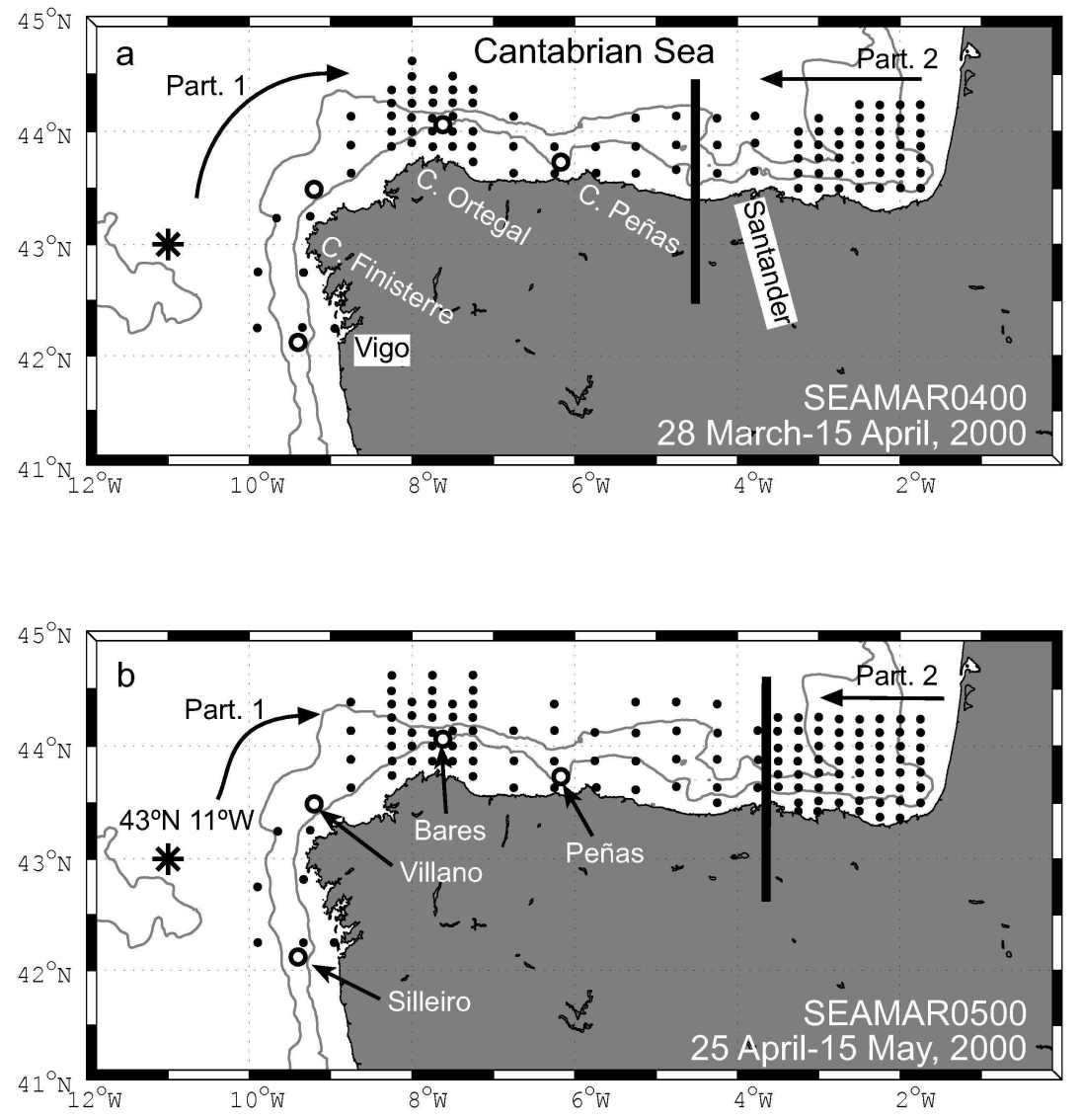
Figure 4. Sea Level Pressure and Wind in the North Atlantic from NOAA-CIRES CDC and subinertial surface currents from the DWN Buoys in the two storms S1 and S2. a) S1 (strong N wind event about April 3, 2000). b) S2 (Persistent SW wind event about 18 April, 2000). c) Surface currents induced by $\mathrm{S} 1$. Thin circles are the average subinertial current speed from January to July at each buoy and black arrows are the currents at the specific date. d) Surface currents induced by S2. Isobaths of 200 and $1000 \mathrm{~m}$ are marked in $(\mathrm{c}, \mathrm{d})$. $266 \times 129 \mathrm{~mm}(600 \times 600 \mathrm{DPI})$ 
Figure 5. a) Potential temperature field at 75 dbar in SM04. b) Same as (a) in SM05. c) Integrated chlorophyll-fluorescence for the first $60 \mathrm{dbar}$ in SM04; d) Same as (c) in SM05. e) Biomass of mesozooplancton DW (mg m-3) in SM04. f) Same as (e) in SM05. Isobaths of 200 and $1000 \mathrm{~m}$ are marked $239 \times 155 \mathrm{~mm}(600 \times 600 \mathrm{DPI})$ 

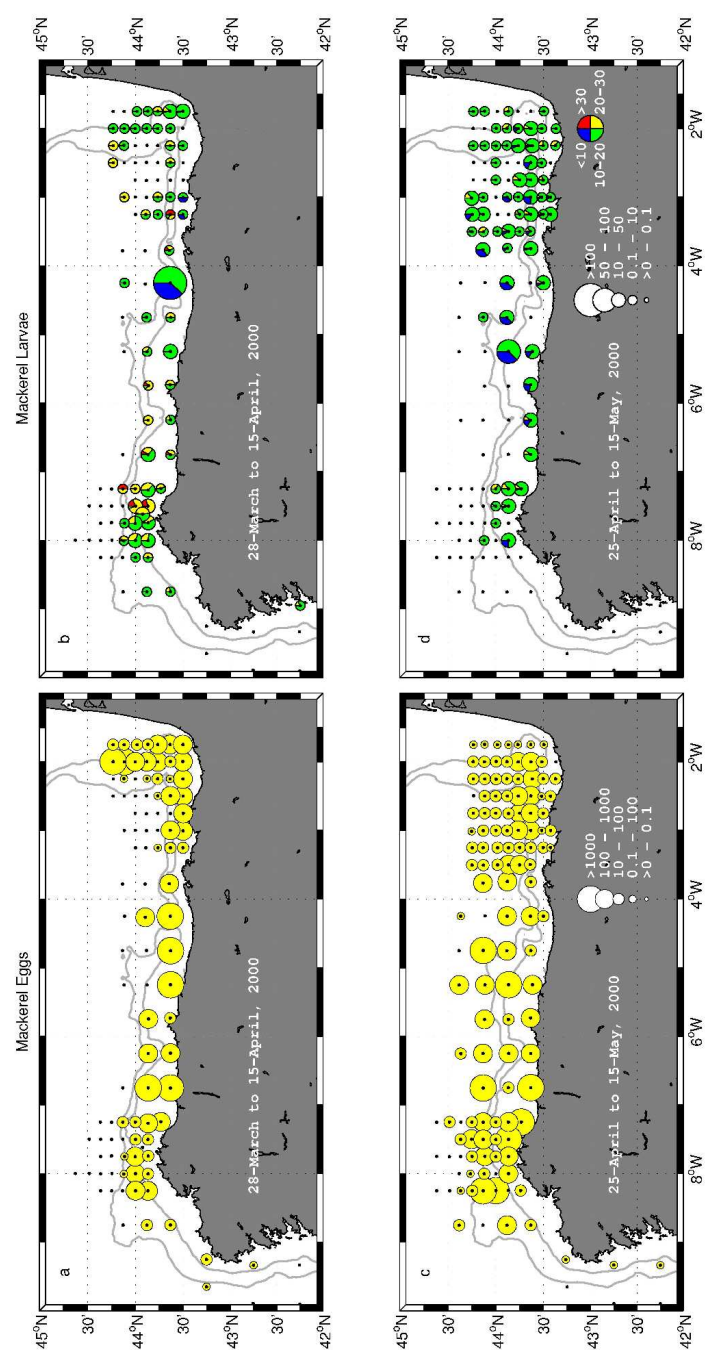

Figure 6. a) Distribution and abundances of mackerel eggs in SM04. b) Distribution and abundances by age class of mackerel larvae-postlarvae in SM04. c) Same as (a) in SM05. d) Same as (b) in SM05. 
Figure 7. Birthdate distribution of mackerel larvae, postlarvae and juveniles in 2000 compared to wind speed cubed (turbulent kinetic energy) daily running mean at the Santander coastal observatory from the same year. $200 \times 144 \mathrm{~mm}(600 \times 600 \mathrm{DPI})$ 


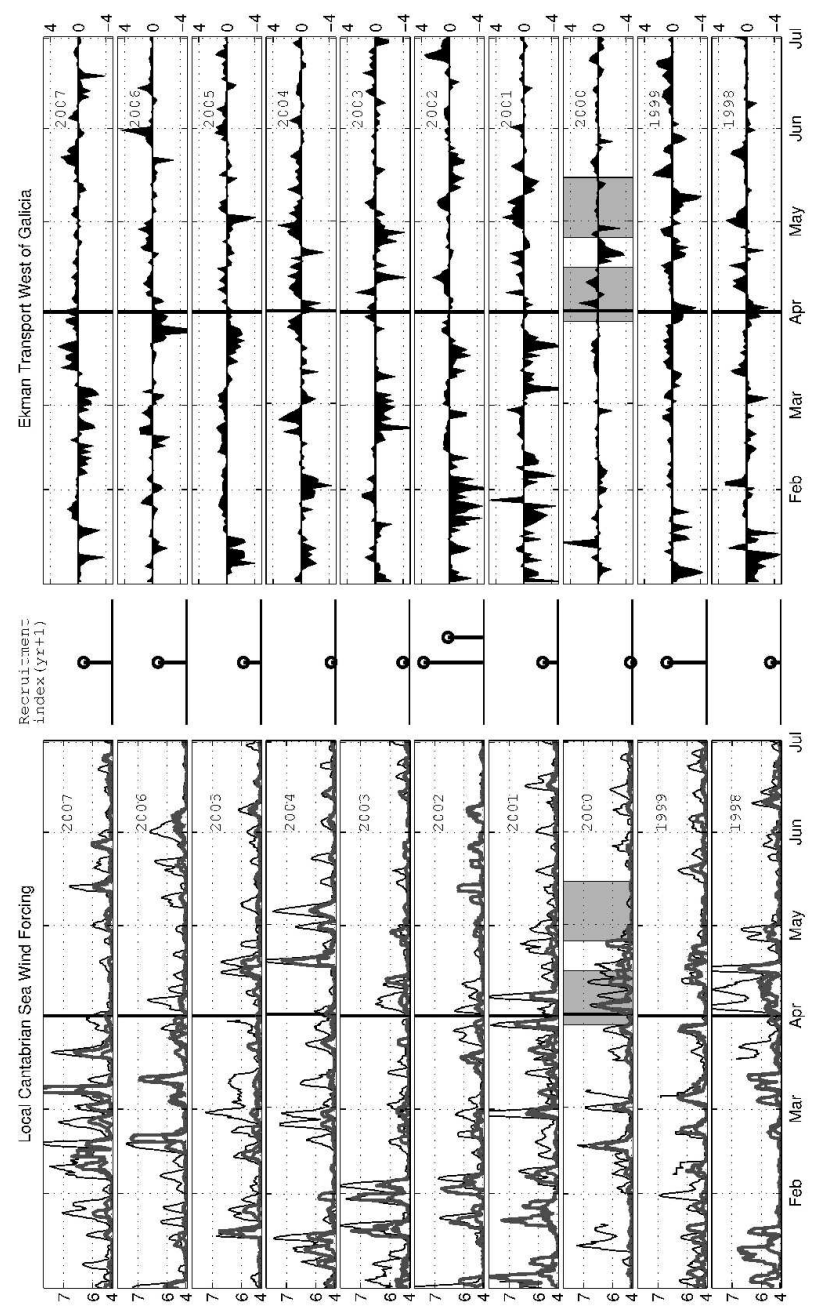

Figure 8. Mackerel recruitment index and meteorological forcing from 1998 to 2007. Left panel) Local wind forcing at the Cantabrian Sea represented as wind speed cubed (proportional to turbulent kinetic energy) daily running mean. Thick lines are coastal observatories of Santander and Peñas Cape from Spanish Meteorological Agency and thin line is the Peñas Buoy from Spanish Port Authorities. Vertical ticks are the Beaufort scale. April 1st is marked with a vertical line. Seamar cruises periods are gray shaded. Right panel) Ekman transport at the reference location West of Galicia -Qx (m3 s-1 km-1) as estimation of the East-West upwelling-downwelling strength in northwestern Iberia (downwelling favourable transports are negative). April 1st is marked with a vertical line. Seamar cruises periods are gray shaded. Middle) Mackerel recruitment index (scaled by the line length) as in Figure 3. Note that year 2002 value is more than double of the next high record so two vertical lines appear. $192 \times 337 \mathrm{~mm}(600 \times 600$ DPI $)$ 
2

3

4

5

7

8

10

11

12

13

14

15

16

17

18

19

20

21

22

23

24

25

26

27

28

29

30

31

34

35

36

37

38

39

40

41

42

43

44

45

46

47

48

49

50

51

52

53

54

55

56

57

58

59

60 \\ Page 57 of 55}

Fisheries Oceanography

1
7
7
7
7
7
8

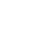

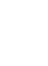

8

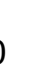

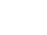

$(15$

7

0

